\title{
Dynamic Impact of the Structure of the Supply Chain of Perishable Foods on Logistics Performance and Food Security
}

\author{
Javier Arturo Orjuela Castro ${ }^{1}$ D, Wilson Adarme Jaimes ${ }^{2}$ \\ ${ }^{1}$ Universidad Distrital Francisco José de Caldas, Bogotá (Colombia) \\ ${ }^{2}$ Universidad Nacional de Colombia (Colombia) \\ jaorjuelac@,unal.edu.co,wadarmej@,unal.edu.co
}

Received: October2016

Accepted: September 2017

\section{Abstract:}

Purpose: Understanding how the structure affects logistical performance and food security is critical in the supply chains of perishable foods (PFSC). This research proposes a system dynamics model to analyse the effects of structures: lean, agile, flexible and responsive, in the overall performance and of each agent of the PFSC.

Design/methodology/approach: Using a system dynamics model and design of experiments it is studied how the different structures and their combination, affect the behaviour of inventory, transportation, responsiveness, efficiency, availability and quality-safety of the fresh fruits supply chain and each echelon.

Findings: The studies of supply chains have been done for each structure in an independent way; investigations are scarce in supply chains of perishable foods. The structures modelled in this research do not show the better performance in all the metrics of the chain, neither in all agents for each structure. The above implies the presence of trade-offs.

Research limitations/implications: The results show the need to investigate mixed structures with the PFSC's own characteristics; the model can be applied in other supply chains of perishable foods. 
Practical implications: Management by combining structures in the PFSC, improves logistics performance and contributes to food security.

Social implications: The agents of the FFSC can apply the structures found in this study, to improve their logistics performance and the food security.

Originality/value: The dynamics of individual and combined structures were identified, which constitutes a contribution to the discussion in the literature of such problems for FFSC. The model includes six echelons: farmers, wholesalers, agro-industry, third-party logistics operators and retailers. The dynamic contemplates deterioration rate to model perishability and others losses.

Keywords: perishable food supply chain structure, dynamic system, fruits

\section{Introduction}

A structure is an individual system of components that when relating to each other determinate the global behavior of the system (Giachetti, Martinez, Sáenz \& Chin-Seng, 2003). The structure of the supply chain (SC) defines the function of each echelon and its processes. Structure and strategy influence each other (Aragón-Correa, Senise-Barrio \& Matías-Reche, 1998). The proper selection of the supply chain structure (supply chain execution - SCE) allows an improvement in the performance of the SC.

Fisher (1997) established the strategy for the SC in light of the nature of demand. While for functional products (long life cycles and stable demand) the SC must be based on efficient processes, in innovative products (short life cycles and a highly unpredictable demand) the SC must be based on sensitive processes. Lee (2002) identified four structures for SCs: efficient, agile, responsive and risk-hiding. In turn, Gattorna (2015) indicates five generic SC types: lean, agile, fully flexible, collaborative Campaign. Perez, Caplice, Singh and Sheffi (2014) developed the Functional Strategy Map to describe a company's CS strategy, which is based on the company's core strategy and the strategic pillars that support it, from which it identifies the strategy and structure of the SC associated to the company.

The problem of the structure of the SC (SCE) has been studied with two approaches, each type of structure individually or combining several typologies (Manson-Jones \& Towill, 1999; Naylor, Naim \& Berry, 1999; Naim \& Gosling, 2011) have evaluated the integration of lean and agile structures for SCs. Agarwal, Shankar and Tiwari (2006) evaluated the metrics for these SCEs. For their part Giachetti et al. (2003) evaluated flexible and agile SCs. Specifically in food, the work of Van der Vorst, Van Dijk and 
Beulens (2001) focuses on identifying the appropriate design for the Poultry Supply Chain (SC); Cozzolino, Rossi and Conforti (2012) evaluated the agile and lean structure in the SC of food in a humanitarian logistics environment; Lyons and Ma'aram (2014) evaluates the classification proposed by Fisher in the food SCs in Greece, finding that lean or agile SC are applied depending on the type of food and the echelon of the chain.

A study of food SCs (SCF) should consider biophysical and organoleptic characteristics, shelf life, production time, transport conditions and storage (Aramyan, Ondersteijn, Van Kooten \& Lansink, 2006). Orjuela-Castro, Calderón and Calderón (2007) evaluates value creation in the SC of physalis, Bourlakis, Maglaras and Fotopoulos (2012) evaluates value creation in Greek SCFs, later Bourlakis, Maglaras, Aktas, Gallear and Fotopoulos (2014), evaluates the sustainability of the sector through the performance measures of consumption, flexibility, responsiveness, product quality and total SC performance. A proposal on taxonomy for the evaluation of logistic performance in the SC is presented in Ruiz-Moreno, Caicedo-Otavo and Orjuela-Castro (2015), based on Orjuela-Castro and Adarme-Jaimes (2014), Aramyan et al. (2006) and Van der Vorst (2005), in which quality, logistical performance, responsiveness, efficiency and demand fulfilment stand out.

The perishability of food commodities generates losses; an estimated one-third of world food production is wasted or damaged (Gustavsson, Cederberg, Sonesson, Van Otterdijk \& Meybeck, 2011). In food supply chains, there is a continuous change in the quality of the product from the moment the raw material leaves the grower, until the product reaches the consumer. The design of the supply chain (CS) of fresh food products, such as fruits, can not be achieved without taking into account the perishability and variability of the products in the chain, in order to deliver the product at the appropriate time, while ensuring the desired level of quality (Dabbene, Gay \& Sacco, 2008a; Dabbene, Gay \& Sacco, 2008b). Food supply chains are global networks, which encompass production, processing, distribution, and even elimination (Yu \& Nagurney, 2013), they are different from other SC (Zanoni \& Zavanella, 2012). The high perishability of food products causes loss of quality and profitability, food decrease and losses are unavoidable (Widodo, Nagasawa, Morizawa \& Ota, 2006), therefore food products often need special, more advanced, transportation and storage solutions (Zhang, Habenicht \& Spieß, 2003; Lowe \& Preckel, 2004; Rong, Akkerman \& Grunow, 2011). Globalization means greater distances between food production and places of consumption; it requires integration of food production and distribution along the chain (Cook, 2002).

Fruits and vegetables show an increasing trend in consumer demand worldwide (Palacio Pelaéz, 2014). The international fruit market has been transformed, boosting its development. The changes and dynamics in consumption have led to a diversity of supply in foreign markets, increasing opportunities for fruit exporting countries such as Colombia (Miranda, 2011). Developing countries account for almost 
$90 \%$ of world fruit production (Manjavacas \& FAO, 2012), developed countries absorb $80 \%$ of the world trade. Latin America and the Caribbean produce 32\% (Miranda, 2011). In this context, a need arises to establish the appropriate structure for the fruit supply chains in countries like Colombia, logistics are considered a fundamental tool for increasing the competitiveness of fruit products, as it contributes to the management of trade from scattered places and to the conservation of products (Malorgio \& Felice, 2014). In the literature review, no studies have been found that evaluate the effect of different structures on the logistic performance measures of SC of perishable fruit (SCPF). This article analyses the effect of the lean, agile, flexible and responsive structures in the logistical performance of the SCFP, applying system dynamics to the case study of the fruit supply chain in Cundinamarca-Bogotá, Colombia, specifically for the citrus fruits orange, tangerine and mango.

\section{Type of Strategies for Supply Chains}

Based on the review of the literature, the following are the characteristics and properties of the kind of structures.

\subsection{SC Lean Structure}

Achieves a low cost by ensuring that clients do not have more service than they require, that they are not over-served (Harrison \& Van Hoek, 2008). These reduced costs are achieved by focusing on the basic processes, eliminating all that does not generate value and guarantee sequencing (Naylor et al., 1999; Gattorna, 2015).

Some of the products assigned to this structure are groceries, basic clothing, food, oil and gasoline, among others (Lee, 2002). The SC Lean (SCL) is essentially characterized by the elimination of waste, the low operational cost, handling of functional products with low variety, with predictable demand such as processed foods. These foods satisfy the basic needs, are stable, have a predictable demand and long life cycles, although their stability generates competition, which results in low margins. A guide for the construction of a SCL can be seen in (Srinivasan, 2012) and its implementation in (Myerson, 2012). 


\subsection{SC Agile Structure}

Focuses on rapid reconfiguration and responsiveness (Manson-Jones \& Towill, 1999). Agility means using business and market knowledge to seize opportunities in a changing and unpredictable demand situation in volatile markets (Naylor et al., 1999). The agility requires of the company a way of acting, organizational structures, information systems and logistical processes (Christopher \& Peck, 2004; Lee, 2002). The SC Agile handles innovative products, with volatile demand. What is essential for this structure is rapid reconfiguration and robustness, it must be able to respond quickly but in a controlled way (Manson-Jones \& Towill, 1999). (Harrison \& Van Hoek, 2008) argue that SC Agile is able to read and respond to an unpredictable demand and high variety, a chain that is in an oscillating flow. Companies with perishable products must manage fast and regular rates of supply, the agile chain has as a strategy to combine coverage and responsiveness (Gattorna, 2015; Lee, 2002).

\subsection{SC Flexible Structure}

Flexibility is defined by (Simchi-Levi, 2010) as the ability to respond to changes without increasing operations or the cost of the supply chain, with little or no delay in response time. The changes in production and logistics environments that require flexibility are: demand, prices, labour costs, exchange rates, technology, equipment availability, market conditions (Simchi-Levi, Schmidt \& Wei, 2014). Flexible SCs require a robust network with the ability to adapt to changes and events, SC agents must be aligned and integrated (Stevenson \& Spring, 2007), flexibility allows for increased security and stability without sacrificing efficiency (Qin, 2011). There are different attitudes toward flexibility in SCFs, (Van der Vorst et al., 2001) assures that food chains are inherently inflexible, because the quest for quality reduces flexibility. The perishability of fresh produce such as fruits and vegetables makes logistics and quality management difficult. On the other hand, consumers demand better sensory properties and a greater variety and food security (Aramyan et al., 2006), the seasonality of some fruits generates the need for flexibility in planting and in agro-industries.

\subsection{SC Responsive Structure}

Also called "Sensitive supply chain" or "continuous replenishment chain" is a strategy that combines the characteristics of the agile and lean SCs. (Gunasekaran, Lai \& Cheng, 2008) define it as a fast-response, costeffective network of companies for a changing and competitive market. The Lean and Agile principles are not mutually exclusive; the two can work in the same SC at different times (Cozzolino et al., 2012). For (Naylor et al., 1999) in the lean-agile structure, agility focuses on service levels for product differentiation, 
while Lean means developing a value chain to eliminate all waste (including time) and ensure a level of sequencing. The operation of a responsive supply chain requires collaboration or integration of different agents (Gattorna, 2015), an evaluation of the effects of the integration of fruit supply chains can be observed in (Orjuela-Castro, Caicedo-Otavo, Ruiz-Moreno \& Adarme-Jaimes, 2016).

\section{Methodology}

Through a systematic review of the literature, the variables and characteristics of the structures of the SCs were identified as shown in Table 1, from which a survey was developed for the agents of the three supply chains of fruits studied: orange, tangerine and mango. The survey included logistical variables associated with procurement, inventory, transportation and distribution, as well as variables of trade, forms and frequency of negotiation. By means of non-probabilistic snowball sampling, 24 producers, 42 retailers (marketplaces and shopkeepers), 12 agroindustry, 37 wholesalers, 7 supermarkets and 14 transporters were surveyed.

\begin{tabular}{|c|c|c|c|c|c|c|c|c|c|c|c|c|}
\hline $\begin{array}{l}\text { Supply } \\
\text { Chain } \\
\text { Structure }\end{array}$ & 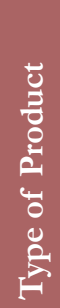 & 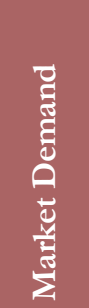 & 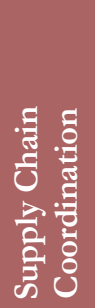 & 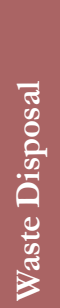 & 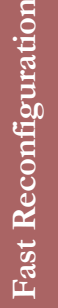 & 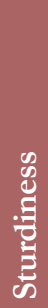 & 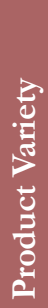 & 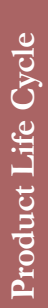 & 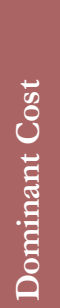 & 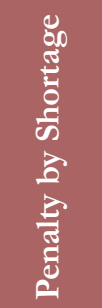 & 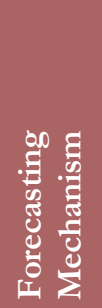 & 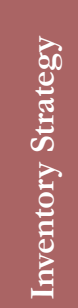 \\
\hline Lean & $\mathrm{Fu}$ & Fo & $\mathrm{Si}$ & $\mathrm{E}$ & $\mathrm{D}$ & A & $\mathrm{L}$ & $\mathrm{L}$ & $\mathrm{O}$ & LT- C & $\mathrm{Al}$ & I-Mi \\
\hline $\begin{array}{l}\text { Responsive } \\
\text { (Lean-Agile) }\end{array}$ & I & Fo-V & $\mathrm{Si}$ & A & $\mathrm{E}$ & $\mathrm{D}$ & M & $\mathrm{S}$ & $\mathrm{M}$ & N-S & Al-Ad & I-Mi \\
\hline Agile & I & $\mathrm{V}$ & $\mathrm{Si}$ & $\mathrm{D}$ & $\mathrm{E}$ & $\mathrm{E}$ & $\mathrm{H}$ & $\mathrm{S}$ & $\mathrm{M}$ & $\mathrm{I}-\mathrm{V}$ & Ad & I-Si \\
\hline Flexible & I & $\mathrm{V}$ & $\mathrm{Si}$ & $\mathrm{D}$ & $\mathrm{E}$ & $\mathrm{E}$ & $\mathrm{H}$ & $\mathrm{L}$ & $\mathrm{O}$ & LT- C & & I-Si \\
\hline Perishable & $\mathrm{Fu}$ & $\mathrm{V}$ & $\mathrm{Si}$ & $\mathrm{E}$ & $\mathrm{D}$ & A & $\mathrm{H}$ & $\mathrm{L}$ & $\mathrm{O}$ & NA & $\mathrm{Al}$-Ad & I-Mi \\
\hline
\end{tabular}

Fu: Functional; I: Innovative; Fo: foreseeable; V: Volatile; E: Essential; D: Desirable; Ar: Arbitrary; L: Low; H: High; L: Long; S: Short; M: Medium; O: Operational; M: Marketer; LT: Long-Term; C: Contract; RN: Right-Now, NS: not Shortage; Al: Algorithmic; AD: Advisor; I: inventory; Mi: Minimum; Ma: Maximum; S: Significant; NA: Not Allow.

Table 1. Characteristics of the SC structures

To measure the performance of the structures in SCs, they were defined as shown in Table 2.

Based on surveys and reports from Agronet, Faostat, Dane and Asohofrucol and Orjuela-Castro, Castañeda-Moreno, Canal-Roa and River-Velasco (2015), the SCs of the three fruits in Cundinamarca-Bogotá were defined: the area of production (ha) and yield ( $\left.\mathrm{t} \mathrm{ha}^{-1}\right)$, the seasonality of 
harvests (months), crop and postharvest losses (t), transport capacities, transit times between echelons (d), loading and unloading times, consumer population and consumption per capita for fresh fruit and pulp ( $\mathrm{g}$-inhabitant/d). Then a system dynamics model was developed using the iThink 9.1.3 software, from which the different scenarios of interest (structures) could be developed.

\begin{tabular}{|c|c|c|c|c|c|}
\hline \multicolumn{6}{|c|}{ Measures of Performance } \\
\hline \multirow{3}{*}{ Responsiveness } & Supply time & \multirow{5}{*}{ Efficiency } & Inventory Cost & \multirow{4}{*}{$\begin{array}{l}\text { Logistics } \\
\text { Performance }\end{array}$} & Inventory Level \\
\hline & $\begin{array}{l}\text { Transformation } \\
\text { Process time }\end{array}$ & & Transport Cost & & $\begin{array}{l}\text { Warehouse } \\
\text { Storage Time }\end{array}$ \\
\hline & Delivery Compliance & & Preparation Cost & & $\begin{array}{l}\text { Transportation } \\
\text { Time }\end{array}$ \\
\hline \multirow{4}{*}{ Quality } & Selection of Suppliers & & Acquisition Cost & & $\begin{array}{l}\text { Rate of Losses } \\
\text { due to Logistical } \\
\text { Processes }\end{array}$ \\
\hline & $\begin{array}{l}\text { Quality of Raw } \\
\text { Materials }\end{array}$ & & Cost of Decay & General & $\begin{array}{l}\text { Consumer } \\
\text { Satisfaction }\end{array}$ \\
\hline & $\begin{array}{l}\text { Biophysical and } \\
\text { Organoleptic } \\
\text { Characteristics }\end{array}$ & & & & \\
\hline & Loss of Food Safety & & & & \\
\hline
\end{tabular}

Table 2. Performance measures of the SCs studied

\section{Description of the Model}

With the primary and secondary information on the behaviour of fruit SCs the SCs of interest was established and the relationships between the echelons that make up the SCs were identified. This model was constructed from different models, the one proposed by (Orjuela-Castro, Casilimas \& Herrera, 2015), which evaluated the capacity of transport infrastructure in Bogota and its effect on food security; the model by (Orjuela-Castro, Sepulveda-Garcia \& Ospina-Contreras, 2016) that studied the intermodality in the logistic performance of PFSCs; the one suggested by (Orjuela-Castro et al., 2016) that established the effects of external integration mechanisms in the logistics of the SC of mango (SCM) and the model in which (Orjuela- Castro, Herrera-Ramírez \& Adarme-Jaimes, 2017) with which the packaging in storage and transport in the SCM is studied. in Figure 1 the commercial relations between agents as PFSC is presented with the name of each agent's common denomination. 


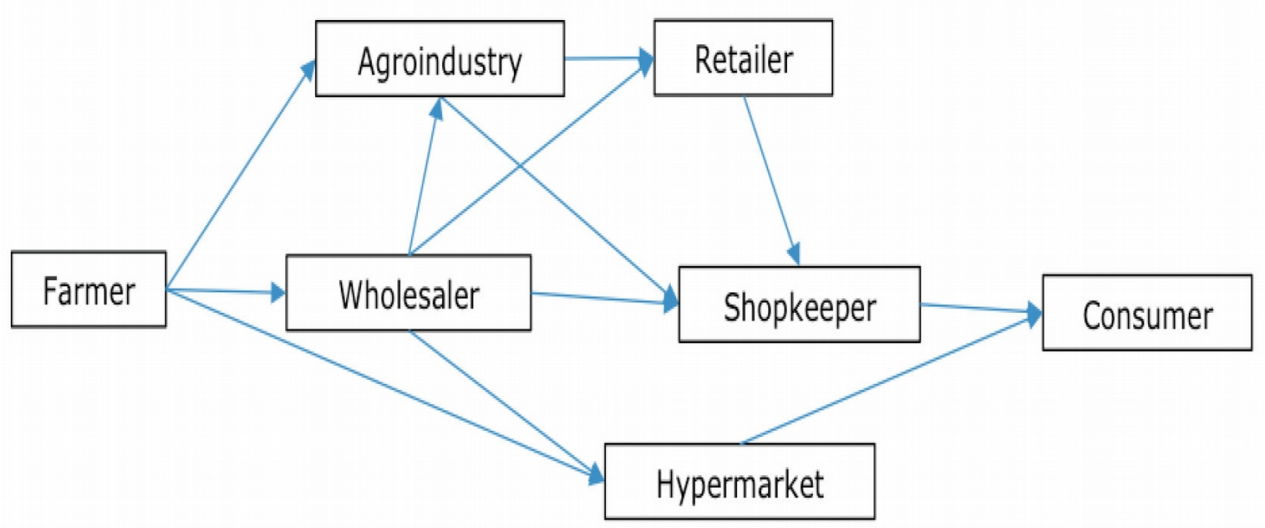

Figure 1. Supply Chain of pesishable Fruit, Colombia

\subsection{Model Structure}

The model for the supply chain of perishable fruits is formed by a set of echelons interconnected by flows and information (Figure 3). One echelon represents a set of agents of the same type, which are as a whole commercially related with other agents downstream and upstream in the chain (Figure 1). The relationships of interest are those associated with the logistics of the chain which is product by trade between agents. The information flows are present through the orders placed by the consumer (the demand) towards the other agents, upstream. The fresh fruit flows are generated from the producer (supply), downstream. The model balances supply-demand through the agents at the centre of the chain, agroindustry and traders, who practically fulfil a function of buffer or regulator. The logistic model of the PFSC, consists mainly of the following variables:

- Consumer demand: obtained from the per capita consumption of each fruit: orange, tangerine and mango, which varies according to the growth of the population of Bogota, demand behaves as a pull system.

- Producer supply: the fruit production depends on yield rates and the number of hectares sown by peasants, here the system behaves as a push system.

- Order generation: the agents at the centre of the SC review their downstream orders and compare them to their inventory, if they do not have enough inventory they place an order upstream.

- Level of Inventory: is the inventory level of each echelon, this changes when receiving product from the echelons upstream and decreases when delivering to the echelons downstream, it also decreases with the losses, which leave the inventory by a rate of perishability. This depends on the 
life cycle of the fruit and is modelled with a delay. Each agent has a minimum level of inventory. The parameters were established by the surveys from each agent.

- Fruit sent: If the agent has enough inventories it will immediately send fruit downstream to fulfil the order. This is done with a delay, due to the processing time of the order. If the agent does not have enough inventories, the order may be breached.

- Fruit in transit: When the fruit leaves the inventory (warehouse) it is handed over for transport. It has been modelled for levels, which allows the determination of travel times and losses due to perishability during the transfer from one agent to another.

\subsection{Dynamics Hyphotesis}

Having established the variables and measures of performance of interest, the causal diagram was constructed, in order to understand the relationships that govern the behaviour of the PFSCs. The causal diagram represented by loops (Figure 2), are shown and described below:

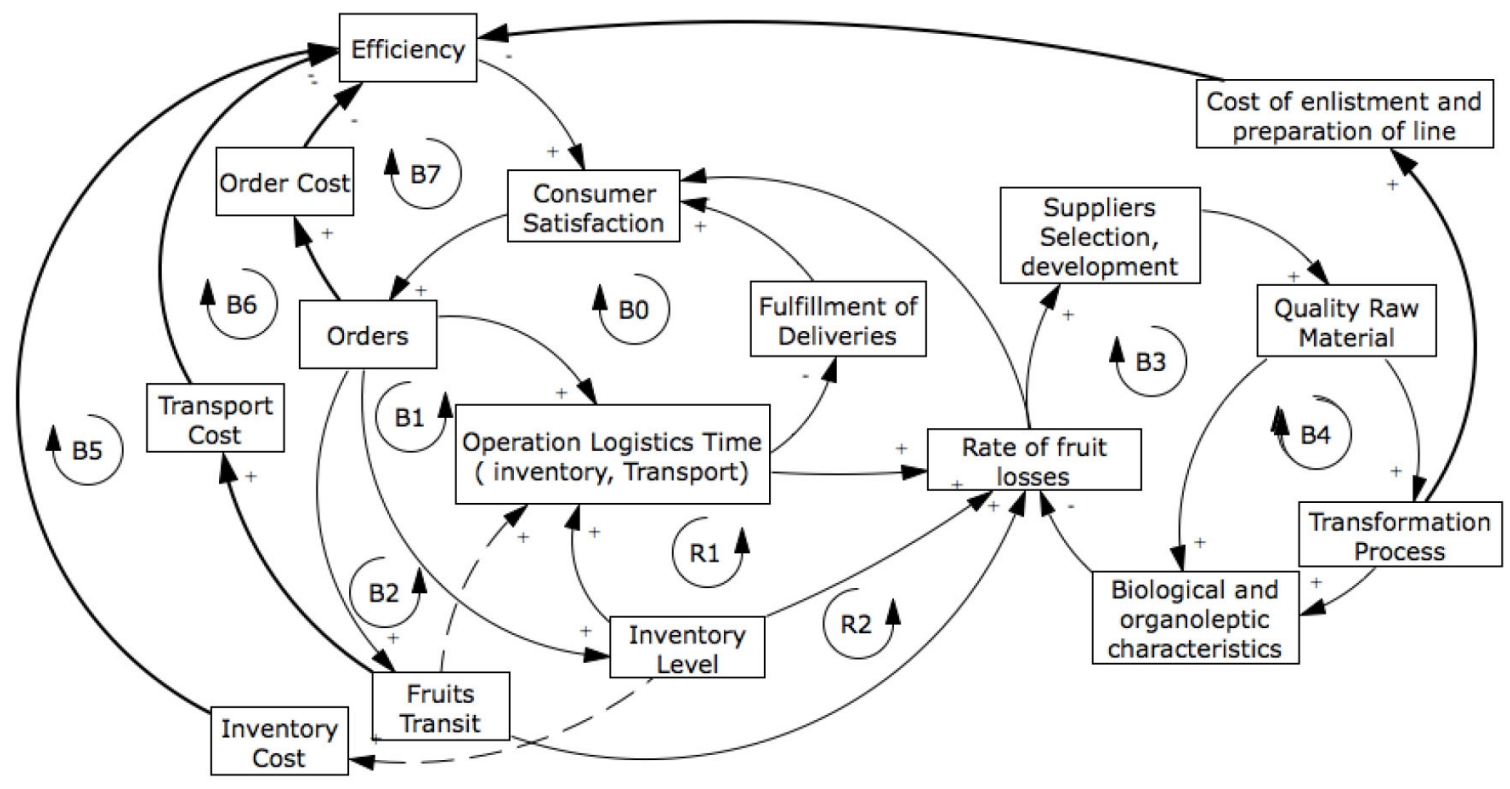

Figure 2. Causal diagram of the relationships between agents

The dynamic hypothesis proposed was: the structure will affect the performance of the whole chain, but not in the same way for all the agents, nor for all the chains of fruits. While for some the performance 
improves for others it will deteriorate. The causal diagram (Figure 2), models the general behaviour of the performance measures variables (Figure 2) described below:

- Quality: Quality is mainly reflected in the losses, as it is important to measure food security. It is affected by several feedback loops: two cycles of positive feedback cycles or reinforcement (R1 and R2) and two negative feedback cycles, self-regulators or homeostatics (B3 and B4). R1: Consumer Satisfaction (CS) - Orders (or) - Inventory Level (IL) - Rate of Fruit Losses (RFL) CS; R2: CS-OR- Fruits Transit (FT) - RFT-CS; Suppliers Selection and Development (SSD) Quality Raw Material (QRM) - Transformation Process (TP) - Biological and Organoleptic Characteristics (BOC) - (SSD). Cycle B3 omits the agroindustry link (transformation process) but applies to the other actors.

- Response Capability: Conformed by self-regulating feedback loops B0, B1 and B2. B0: CS - OR Operation Logistic Time (OLT) - Fulfilment of Deliveries (FD) - CS; B1: CS-OR-IL-OLT-FDCS. B2: CS-OR-FT-OLT-FD-CS.

- Efficiency of Logistics Operations: which affect the cycles B1, B2, R1, R2.

- Efficiency - Costs: which are derived from the cycles: Inventory Cost (B5), Transport Cost (B6) and Order Cost (B7). B5: CS-OR-IL-Inventory Cost (IC) -E-CS; B6: CS -OR-FT -TC-E-CS; B7: CS O - Order Cost (OC) - E - CS.

Another measure of performance is the one related to customer satisfaction or consumer satisfaction in the case of the end customer. As can be seen in the cycles it is affected by all the factors.

The way in which one variable affects another is represented by arcs. A positive bow $(+)$ when an increase in the preceding variable causes (cause) an increase in its successor variable (consequence) and a negative bow (-) when the decrease of the preceding variable causes a decrease of the successor variable.

\subsection{Forrester's Model}

The SCPF was modelled in System Dynamic with iThink, where the three modelled SCPFs mango, tangerine and orange are contemplated, both fresh and processed fruit are included. In fact, the model is configured as multi-echelon and multi-product, whose complexity derives from contemplating the producers, wholesalers, agro-industries, retailers, consumers, their logistics, the flows of fruit and the relations between the agents based on Forrester (1958) and Sterman (2000) (Figure 3). The chain of mango is presented in the figure, nevertheless in a same model the three chains were modelled, in order to be able to model the flexible chains. 


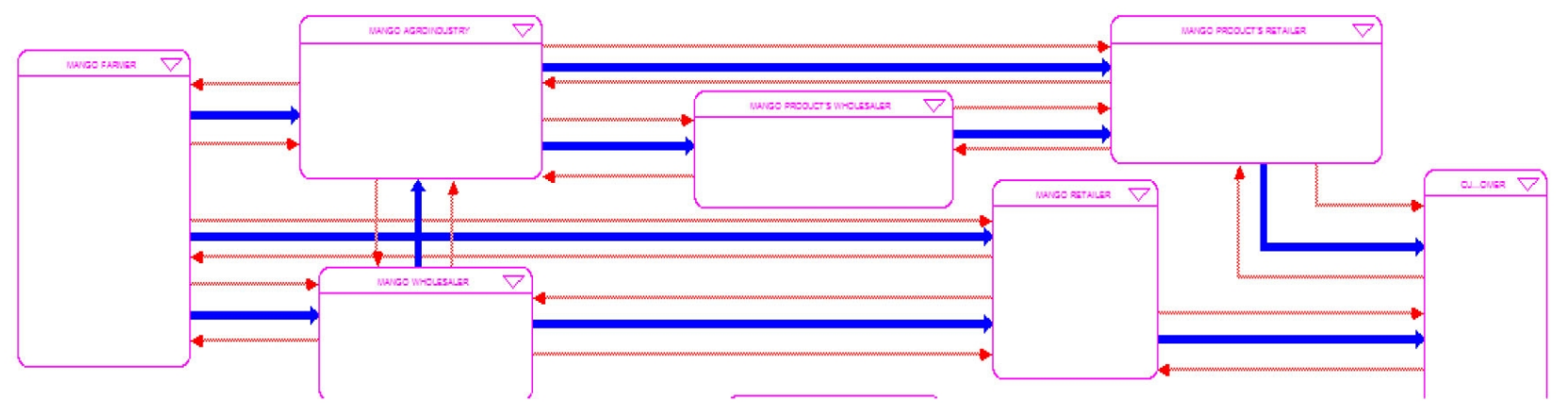

Figure 3. Model for 3 SCPF in iThink of the echelons, their material (blue) and information flows (red)

\subsection{Model Equations}

The system dynamics model includes flow equations, with level and auxiliary variables such as delays. Since it is a dynamic model the differential equations are used for flows and levels with respect to time. Logistics equations such as inventories, transportation, orders and losses as well as demand and supply are presented below. Examples are included for some echelons and for a fruit supply chain. The equations for inventory management are based on Sterman, 2000.

\section{Discussion of Results}

The experimental design of this research follows the steps of (Yasarcan, 2011), in which he carries out 5 simulations for each proposed scenario, using a different seed value in each simulation. The values chosen were 1, 2, 3, 4 and 5. The model has stochastic parameters, for which several runs were made with different seed for each scenario. Below the average results: The simulation time is 10 years, i.e. 3650 days to evaluate the long-term effect on the use of a structure, a DT $=0.5$ was used. The distribution channels are as follows: (Channel 1) Farmer - Fruit Distributor - Fruit Sales Point; (Channel 2) Farmer Agroindustry - Sales point; (Channel 3) Farmer - Fruit Distributor - Agroindustry. 


\begin{tabular}{|c|c|c|c|c|c|c|}
\hline \multirow[b]{2}{*}{ Variables } & \multirow[b]{2}{*}{ Chains } & \multicolumn{5}{|c|}{ SCENARIO STRUCTURE } \\
\hline & & Current chain & Agile & Responsive & Lean & Flexible \\
\hline \multirow{3}{*}{$\begin{array}{l}\text { Adjustment of } \\
\text { production }\end{array}$} & Mango & \multirow{3}{*}{1} & 1.25 & 0.75 & 0.75 & 1.25 \\
\hline & Tangerine & & 1.44 & 0.56 & 0.56 & 1.44 \\
\hline & Orange & & 1.24 & 0.76 & 0.76 & 1.24 \\
\hline Type of vehicles & All chains & 2 & 1 & 1 & 3 & 2 \\
\hline Use of the machines & All chains & 1 & 1.5 & 1.5 & 0.5 & 1 \\
\hline $\begin{array}{l}\text { Order processing } \\
\text { adjustment }\end{array}$ & All chains & 1 & 0.5 & 0.5 & 2 & 0.5 \\
\hline
\end{tabular}

Table 3. Changes of parameters for the scenarios

Performance measures for the three fruit chains, orange, mango and tangerine, are presented for the five structures: current, agile, responsive, lean and flexible. The tables are sorted by fruit and by the global measures of performance, in some cases they are shown for the chain and in others by agent. In addition, in order to evaluate the dynamics over time, the behaviour of the variables of the three chains are presented by performance measurement during a 10-year period. With the purpose of establishing the structure of the SCPFs in Cundinamarca-Bogota, scenarios were created. A first scenario models the current chain; the others simulate the other four structures. The Table 3 shows the variables used and the change in each scenario.

The assignment of values for the adjustment of the yield in the production assumed a normal distribution. The vehicle capacities for type 1,2, and 3 were 1, 5 and 10 tons, respectively. The machines work 2 shifts for the current one, and change as shown in Table 3. This was assigned to the process for the current chain, since it manages $100 \%$, see graph for the other scenarios. These evaluations were performed based on the characteristics of each structure as shown in Table 1. Next the analysis by categories of the performance measurements is presented. The best performance measure has been highlighted.

\subsection{Aggregated Results}

- Response Capability: In Table 4 the results of the five settings are presented for each one of the three fruits. 


\begin{tabular}{|l|r|r|r|}
\cline { 2 - 4 } \multicolumn{1}{c|}{} & \multicolumn{3}{c|}{ Lead Time (day) } \\
\cline { 2 - 4 } \multicolumn{1}{c|}{ Chanel 1 } & Chanel 2 & \multicolumn{1}{c|}{ Chanel 3 } \\
\hline Current & 0.79 & 0.52 & 1.12 \\
\hline Agile & $\mathbf{0 . 5 5}$ & $\mathbf{0 . 2 9}$ & $\mathbf{0 . 6 8}$ \\
\hline Responsive & $\mathbf{0 . 5 5}$ & $\mathbf{0 . 2 9}$ & $\mathbf{0 . 6 8}$ \\
\hline Lean & 1.27 & 0.98 & 1.99 \\
\hline Flexible & 0.58 & 0.31 & 0.7 \\
\hline
\end{tabular}

\begin{tabular}{|r|r|}
\hline \multicolumn{2}{|c|}{ Demand Fulfillment (\%) } \\
\hline \multicolumn{1}{|c|}{ Mango } & \multicolumn{1}{|c|}{ Mango pulp } \\
\hline $94.17 \%$ & $\mathbf{2 0 . 4 8 \%}$ \\
\hline $95.61 \%$ & $20.02 \%$ \\
\hline $90.87 \%$ & $19.77 \%$ \\
\hline $91.58 \%$ & $\mathbf{2 0 . 4 3} \%$ \\
\hline $\mathbf{9 5 . 9 4 \%}$ & $19.90 \%$ \\
\hline
\end{tabular}

Table 4a. Leadtime and Demand fulfilment for Mango

\begin{tabular}{|l|r|r|r|}
\cline { 2 - 4 } \multicolumn{1}{c|}{} & \multicolumn{3}{|c|}{ Lead Time (day) } \\
\cline { 2 - 4 } \multicolumn{1}{c|}{} & Chanel 1 & \multicolumn{1}{c|}{ Chanel 2 } & \multicolumn{1}{c|}{ Chanel 3 } \\
\hline Current & 0.79 & 0.52 & 1.12 \\
\hline Agile & $\mathbf{0 . 5 5}$ & $\mathbf{0 . 2 9}$ & $\mathbf{0 . 6 8}$ \\
\hline Responsive & $\mathbf{0 . 5 5}$ & $\mathbf{0 . 2 9}$ & $\mathbf{0 . 6 8}$ \\
\hline Lean & 1.27 & 0.98 & 1.99 \\
\hline Flexible & 0.58 & 0.31 & 0.7 \\
\hline
\end{tabular}

\begin{tabular}{|r|r|}
\hline \multicolumn{2}{|c|}{ Demand Fulfilment $(\%)$} \\
\hline \multicolumn{1}{|c|}{ Orange } & Orange pulp \\
\hline $10.71 \%$ & $18.16 \%$ \\
\hline $12.84 \%$ & $20.92 \%$ \\
\hline $8.02 \%$ & $14.69 \%$ \\
\hline $8.03 \%$ & $14.56 \%$ \\
\hline $\mathbf{1 3 . 3 9} \%$ & $\mathbf{2 1 . 6 3} \%$ \\
\hline
\end{tabular}

Table 4b. Leadtime and Demand fulfilment for Orange

\begin{tabular}{|l|r|r|r|}
\cline { 2 - 4 } \multicolumn{1}{c|}{} & \multicolumn{3}{c|}{ Lead Time (day) } \\
\cline { 2 - 4 } \multicolumn{1}{c|}{ Chanel 1 } & Chanel 2 & \multicolumn{1}{c|}{ Chanel 3 } \\
\hline Current & 0.79 & 0.52 & 1.12 \\
\hline Agile & $\mathbf{0 . 5 5}$ & $\mathbf{0 . 2 9}$ & $\mathbf{0 . 6 8}$ \\
\hline Responsive & $\mathbf{0 . 5 5}$ & $\mathbf{0 . 2 9}$ & $\mathbf{0 . 6 8}$ \\
\hline Lean & 1.27 & 0.98 & 1.99 \\
\hline Flexible & 0.58 & 0.31 & 0.7 \\
\hline
\end{tabular}

\begin{tabular}{|r|r|}
\hline \multicolumn{2}{|c|}{ Demand Fulfilment (\%) } \\
\hline \multicolumn{1}{|c|}{ Tangerine } & Tangerine pulp \\
\hline $95.35 \%$ & $25.23 \%$ \\
\hline $95.26 \%$ & $24.68 \%$ \\
\hline $95.24 \%$ & $\mathbf{2 4 . 5 4 \%}$ \\
\hline $\mathbf{9 5 . 4 4 \%}$ & $25.52 \%$ \\
\hline $95.25 \%$ & $24.54 \%$ \\
\hline
\end{tabular}

Table 4c. Leadtime and Demand fulfilment for Tangerine

For the lead time, it is clear that the agile and responsive structures are the best, as was expected. As for meeting of demand, the best chain varies in the case of processed food. For mango, the current chain is the best one followed by lean, for orange the flexible is the best one, and for tangerine it is responsive. For fresh fruit, the flexible structure is the best one for mango and orange, while for tangerine it is lean.

- Quality: In Table 5 losses caused in inventory are presented, and in Table 6 transport losses are presented. 


\begin{tabular}{|l|r|r|r|r|r|}
\cline { 2 - 6 } & \multicolumn{5}{c|}{ Percentage Improvement Waste Inventory (Over Current) } \\
\cline { 2 - 6 } & \multicolumn{5}{c|}{ Mango } \\
\cline { 2 - 6 } & Farmer & Agroindustry & Wholesaler & \multicolumn{1}{c|}{ Retailer } & \multicolumn{1}{c|}{ Chain } \\
\hline Agile & $23.3 \%$ & $-2.3 \%$ & $25.4 \%$ & $-0.2 \%$ & $46.3 \%$ \\
\hline Responsive & $-29.3 \%$ & $-\mathbf{3 . 1} \%$ & $-31.9 \%$ & $-\mathbf{0 . 3} \%$ & $-\mathbf{6 4 . 6} \%$ \\
\hline Lean & $\mathbf{- 3 0 . 9} \%$ & $4.4 \%$ & $-\mathbf{3 4 . 2} \%$ & $9.4 \%$ & $-51.4 \%$ \\
\hline Flexible & $29.7 \%$ & $-2.8 \%$ & $32.3 \%$ & $-0.2 \%$ & $59.0 \%$ \\
\hline
\end{tabular}

Table 5a. Waste Inventory for Mango

\begin{tabular}{|c|c|c|c|c|c|}
\hline & \multicolumn{5}{|c|}{ Percentage Improvement Waste Inventory (Over Current) } \\
\hline & \multicolumn{5}{|c|}{ Orange } \\
\hline & Farmer & Agroindustry & Wholesaler & Retailer & Chain \\
\hline Agile & $19.1 \%$ & $15.2 \%$ & $20.4 \%$ & $19.9 \%$ & $74.6 \%$ \\
\hline Responsive & $-24.1 \%$ & $-19.1 \%$ & $-25.6 \%$ & $-25.0 \%$ & $-93.9 \%$ \\
\hline Lean & $-23.6 \%$ & $-19.8 \%$ & $-25.1 \%$ & $-25.0 \%$ & $-93.5 \%$ \\
\hline Flexible & $24.0 \%$ & $19.1 \%$ & $25.6 \%$ & $25.1 \%$ & $93.8 \%$ \\
\hline
\end{tabular}

Table 5b. Waste Inventory for Orange

\begin{tabular}{|l|r|r|r|r|r|}
\cline { 2 - 6 } & \multicolumn{5}{c|}{ Percentage Improvement Waste Inventory (Over Current) } \\
\cline { 2 - 6 } & \multicolumn{5}{c|}{ Tangerine } \\
\cline { 2 - 6 } & Farmer & Agroindustry & Wholesaler & \multicolumn{1}{c|}{ Retailer } & \multicolumn{1}{c|}{ Chain } \\
\hline Agile & $-2.2 \%$ & $36.8 \%$ & $\mathbf{- 0 . 3} \%$ & $70.6 \%$ & $104.9 \%$ \\
\hline Responsive & $\mathbf{- 2 . 7 \%}$ & $-46.0 \%$ & $-0.1 \%$ & $\mathbf{- 9 4 . 0 \%}$ & $-\mathbf{1 4 2 . 8 \%}$ \\
\hline Lean & $1.2 \%$ & $-\mathbf{4 6 . 1 \%}$ & $0.8 \%$ & $-89.4 \%$ & $-133.4 \%$ \\
\hline Flexible & $\mathbf{- 2 . 7 \%}$ & $46.0 \%$ & $-0.2 \%$ & $88.3 \%$ & $131.4 \%$ \\
\hline
\end{tabular}

Table 5c. Waste Inventory for Tangerine

According to the total performance structures the best structure for losses caused in inventory is responsive. However, it differs between actors. For the farmer, responsive is better for orange and tangerine, while for mango it is lean. The differences can be seen in Table 5 .

Unlike the losses caused in inventory, for transport losses the best structure for the chain as a whole is flexible. However, different agents benefit from different structures, see Table 6. 


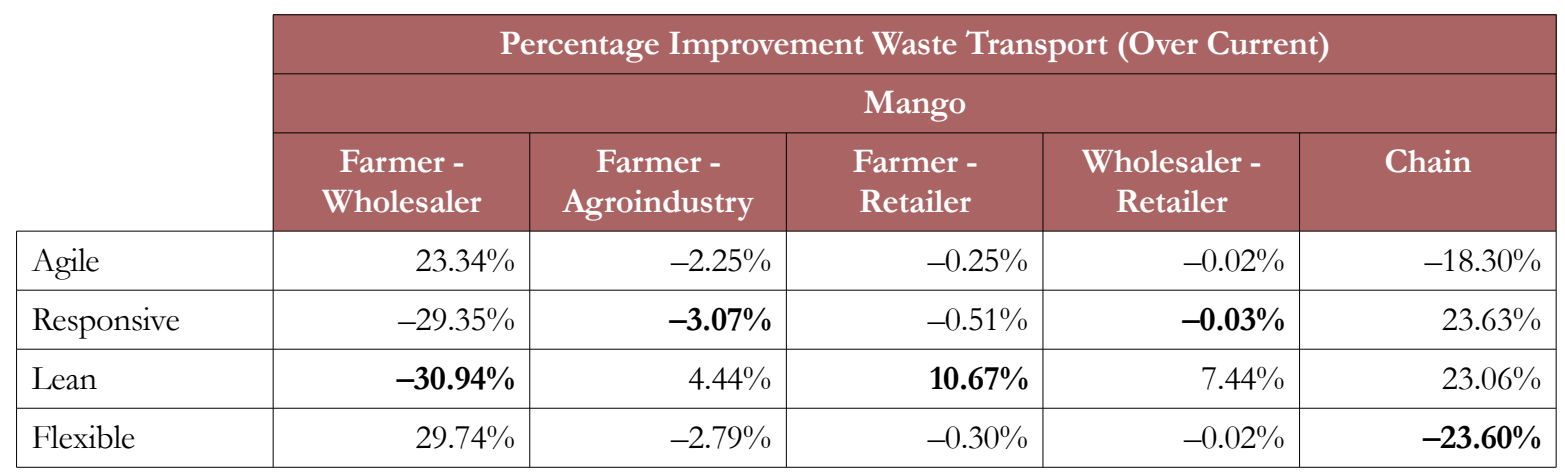

Table 6a. Waste Transport for Mango

\begin{tabular}{|l|r|r|r|r|r|r|}
\cline { 2 - 7 } & \multicolumn{6}{c|}{ Percentage Improvement Waste Transport (Over Current) } \\
\cline { 2 - 7 } & \multicolumn{7}{|c|}{$\begin{array}{c}\text { Farmer - } \\
\text { Wholesaler }\end{array}$} & $\begin{array}{c}\text { Farmer - } \\
\text { Agroindustr } \\
\text { y }\end{array}$ & $\begin{array}{c}\text { Farmer - } \\
\text { Retailer }\end{array}$ & $\begin{array}{c}\text { Wholesaler - } \\
\text { Agroindustr } \\
\text { y }\end{array}$ & $\begin{array}{c}\text { Wholesaler - } \\
\text { Retailer }\end{array}$ & Chain \\
\hline Agile & $19.16 \%$ & $19.15 \%$ & $19.15 \%$ & $-0.02 \%$ & $20.36 \%$ & $-19.12 \%$ \\
\hline Responsive & $\mathbf{- 2 4 . 0 8 \%}$ & $-24.10 \%$ & $-24.10 \%$ & $\mathbf{- 0 . 0 3 \%}$ & $\mathbf{- 2 5 . 5 9 \%}$ & $24.04 \%$ \\
\hline Lean & $-23.51 \%$ & $\mathbf{- 2 5 . 6 5 \%}$ & $\mathbf{- 2 4 . 7 1 \%}$ & $2.55 \%$ & $-25.15 \%$ & $23.87 \%$ \\
\hline Flexible & $24.11 \%$ & $24.09 \%$ & $24.09 \%$ & $\mathbf{- 0 . 0 3 \%}$ & $25.61 \%$ & $\mathbf{- 2 4 . 0 5 \%}$ \\
\hline
\end{tabular}

Table 6b. Waste Transport for Orange

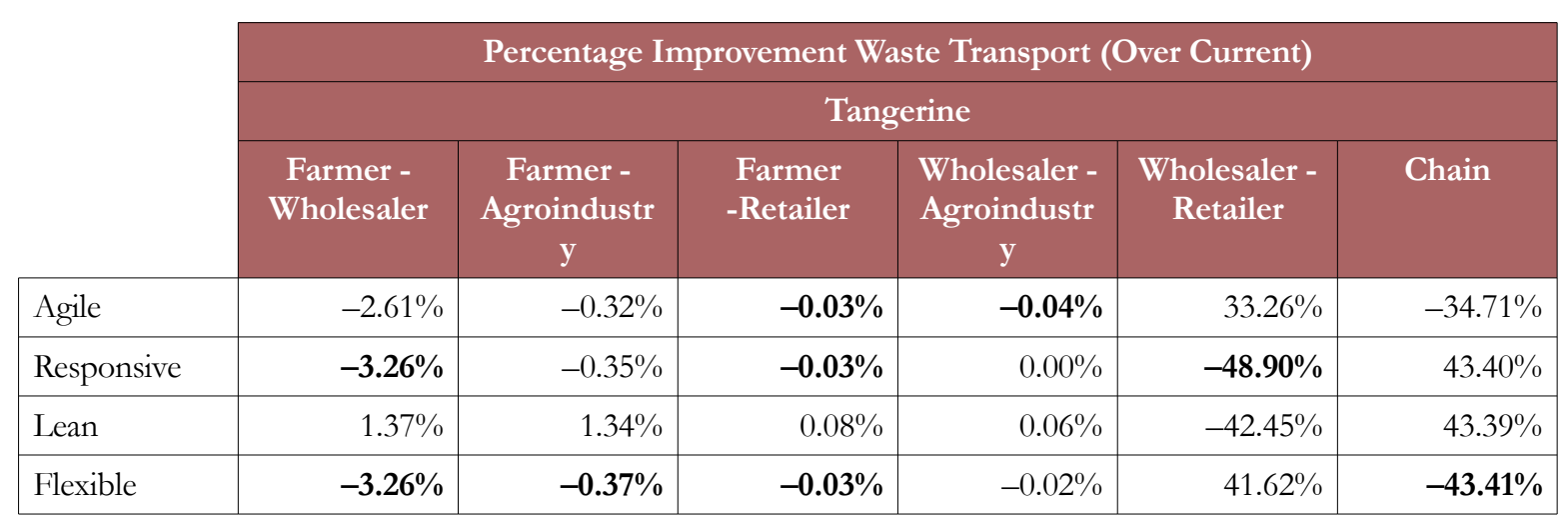

Table 6c. Waste Transport for Tangerine

- Efficiency of Logistics Operations: Logistics operations relate mainly to inventories and transportation. For this reason, the aggregated behaviour is presented below. Tables 7 show the inventories 


\begin{tabular}{|l|r|r|r|r|r|r|r|r|r|}
\cline { 2 - 10 } & \multicolumn{7}{c|}{ Percentage Improvement Inventory (Over Current) } \\
\cline { 2 - 10 } & \multicolumn{7}{|c|}{ Orange } & \multicolumn{4}{c|}{ Orange Pulp } \\
\hline Farmer & Agroindustry & Wholesaler & Retailer & Chain & Agroindustry & Wholesaler & Retailer & Chain \\
\hline Responsive & $-16.0 \%$ & $11.5 \%$ & $57.0 \%$ & $1.6 \%$ & $104.1 \%$ & $20.7 \%$ & $20.3 \%$ & $18.8 \%$ & $59.8 \%$ \\
\hline Lean & $-29.9 \%$ & $-18.4 \%$ & $-70.3 \%$ & $-11.6 \%$ & $-130.2 \%$ & $-29.9 \%$ & $2.4 \%$ & $-36.6 \%$ & $-64.1 \%$ \\
\hline Flexible & $50.8 \%$ & $19.7 \%$ & $82.6 \%$ & $1.7 \%$ & $154.8 \%$ & $30.2 \%$ & $29.6 \%$ & $28.1 \%$ & $87.8 \%$ \\
\hline
\end{tabular}

Table 7a. Percentage Change inventory for Mango

\begin{tabular}{|c|c|c|c|c|c|c|c|c|c|}
\hline & \multicolumn{9}{|c|}{ Percentage Improvement Inventory (Over Current) } \\
\hline & \multicolumn{5}{|c|}{ Orange } & \multicolumn{4}{|c|}{ Orange Pulp } \\
\hline & Farmer & Agroindustry & Wholesaler & Retailer & Chain & Agroindustry & Wholesaler & Retailer & Chain \\
\hline Agile & $44.40 \%$ & $1.16 \%$ & $15.14 \%$ & $16.45 \%$ & $77.15 \%$ & $23.3 \%$ & $-2.3 \%$ & $25.4 \%$ & $46.3 \%$ \\
\hline Responsive & $-3.34 \%$ & $-33.71 \%$ & $-27.20 \%$ & $-26.25 \%$ & $-90.50 \%$ & $-29.3 \%$ & $-3.1 \%$ & $-31.9 \%$ & $-64.6 \%$ \\
\hline Lean & $-30.90 \%$ & $-19.52 \%$ & $-22.21 \%$ & $-19.37 \%$ & $-92.00 \%$ & $-30.9 \%$ & $4.4 \%$ & $-34.2 \%$ & $-51.4 \%$ \\
\hline Flexible & $57.24 \%$ & $2.30 \%$ & $20.12 \%$ & $21.73 \%$ & $101.38 \%$ & $29.7 \%$ & $-2.8 \%$ & $32.3 \%$ & $59.0 \%$ \\
\hline
\end{tabular}

Table 7b. Percentage Change inventory for Orange

\begin{tabular}{|c|c|c|c|c|c|c|c|c|c|}
\hline & \multicolumn{9}{|c|}{ Percentage Improvement Inventory (Over Current) } \\
\hline & \multicolumn{5}{|c|}{ Tangerine } & \multicolumn{4}{|c|}{ Orange Tangerine } \\
\hline & Farmer & Agroindustry & \begin{tabular}{|l|} 
Wholesaler \\
\end{tabular} & Retailer & Chain & Agroindustry & Wholesaler & Retailer & Chain \\
\hline Agile & $-36 \%$ & $0 \%$ & $-48 \%$ & $1 \%$ & $70 \%$ & $-2 \%$ & $-2 \%$ & $-2 \%$ & $-6 \%$ \\
\hline Responsive & $-48 \%$ & $0 \%$ & $-44 \%$ & $0 \%$ & $-92 \%$ & $-3 \%$ & $-2 \%$ & $-2 \%$ & $-7 \%$ \\
\hline Lean & $-54 \%$ & $-2 \%$ & $-44 \%$ & $1 \%$ & $-99 \%$ & $2 \%$ & $-94 \%$ & $41 \%$ & $-50 \%$ \\
\hline Flexible & $37 \%$ & $0 \%$ & $50 \%$ & $0 \%$ & $86 \%$ & $-3 \%$ & $-2 \%$ & $-2 \%$ & $-7 \%$ \\
\hline
\end{tabular}

Table 7c. Percentage Change inventory for tangerine

The analysis of inventories cannot be done independently. For the agile structure, for example, it is necessary to have a larger inventory, while the lean structure requires a smaller inventory. The results for transportation are presented below. 


\begin{tabular}{|l|r|r|r|r|r|r|}
\cline { 2 - 7 } & \multicolumn{6}{|c|}{ Percentage Improvement Transport (Over Current) } \\
\cline { 2 - 7 } & \multicolumn{3}{c|}{ Mango } & \multicolumn{3}{c|}{ Mango Pulp } \\
\cline { 2 - 7 } & \multicolumn{1}{c|}{ Farmer } & \multicolumn{1}{c|}{ Wholesaler } & \multicolumn{1}{c|}{ Chain } & Agroindustry & Wholesaler & Chain \\
\hline Agile & $8.4 \%$ & $0.8 \%$ & $6.9 \%$ & $20.8 \%$ & $18.4 \%$ & $20.0 \%$ \\
\hline Responsive & $-31.4 \%$ & $-1.1 \%$ & $-25.2 \%$ & $-23.3 \%$ & $-25.7 \%$ & $-24.2 \%$ \\
\hline Lean & $-13.9 \%$ & $-1.3 \%$ & $-11.3 \%$ & $-29.9 \%$ & $-84.9 \%$ & $-49.3 \%$ \\
\hline Flexible & $\mathbf{1 3 . 6 \%}$ & $\mathbf{1 . 0} \%$ & $\mathbf{1 1 . 0} \%$ & $\mathbf{3 0 . 4} \%$ & $\mathbf{2 7 . 4} \%$ & $\mathbf{2 9 . 3} \%$ \\
\hline
\end{tabular}

Table 8a. Percentage Change transport for mango

\begin{tabular}{|l|r|r|r|r|r|r|}
\cline { 2 - 7 } & \multicolumn{6}{|c|}{ Percentage Improvement Transport (Over Current) } \\
\cline { 2 - 7 } & \multicolumn{3}{|c|}{ Orange } & \multicolumn{3}{c|}{ Orange Pulp } \\
\cline { 2 - 7 } & \multicolumn{1}{c|}{ Farmer } & \multicolumn{1}{c|}{ Wholesaler } & \multicolumn{1}{c|}{ Chain } & Agroindustry & Wholesaler & Chain \\
\hline Agile & $0.6 \%$ & $29.0 \%$ & $7.3 \%$ & $22.3 \%$ & $15.3 \%$ & $19.9 \%$ \\
\hline Responsive & $-37.5 \%$ & $-15.4 \%$ & $-32.3 \%$ & $-13.7 \%$ & $-18.8 \%$ & $-15.4 \%$ \\
\hline Lean & $-20.8 \%$ & $-15.9 \%$ & $-19.6 \%$ & $-28.3 \%$ & $-88.0 \%$ & $-48.3 \%$ \\
\hline Flexible & $\mathbf{1 . 6} \%$ & $\mathbf{3 7 . 7} \%$ & $\mathbf{1 0 . 1} \%$ & $\mathbf{2 8 . 8} \%$ & $\mathbf{1 9 . 9} \%$ & $\mathbf{2 5 . 8} \%$ \\
\hline
\end{tabular}

Table 8b. Percentage Change transport for Orange

\begin{tabular}{|l|r|r|r|r|r|r|}
\cline { 2 - 7 } & \multicolumn{6}{c|}{ Mercentage Improvement Transport (Over Current) } \\
\cline { 2 - 7 } & \multicolumn{3}{c|}{ Mango } & \multicolumn{3}{c|}{ Mango Pulp } \\
\cline { 2 - 7 } & Farmer & \multicolumn{1}{c|}{ Wholesaler } & \multicolumn{1}{c|}{ Chain } & Agroindustry & Wholesaler & Chain \\
\hline Agile & $\mathbf{3 0 . 6 \%}$ & $\mathbf{0 . 9} \%$ & $30.2 \%$ & $-2.0 \%$ & $-21.0 \%$ & $-8.5 \%$ \\
\hline Responsive & $-46.1 \%$ & $0.0 \%$ & $-45.4 \%$ & $-2.4 \%$ & $-2.2 \%$ & $-2.3 \%$ \\
\hline Lean & $-43.0 \%$ & $0.1 \%$ & $-42.4 \%$ & $-\mathbf{- 1 . 2} \%$ & $\mathbf{6 7 . 8} \%$ & $\mathbf{2 2 . 6 \%}$ \\
\hline Flexible & $38.7 \%$ & $-0.2 \%$ & $\mathbf{3 8 . 2} \%$ & $-2.4 \%$ & $-2.2 \%$ & $-2.3 \%$ \\
\hline
\end{tabular}

Table 8c. Percentage Change transport for Tangerine

It is observed that the best structure for tangerine is the lean one, while for mango and orange the best one is the flexible.

- Efficiency - Costs: The efficiency was measured through cost. The Tables 9 show the changes of strategy in comparison to the current chain. 


\begin{tabular}{|l|r|r|r|r|r|}
\cline { 2 - 6 } \multicolumn{1}{c|}{} & \multicolumn{5}{c|}{ Percentage improvement of cost over current, Mango } \\
\cline { 2 - 6 } \multicolumn{1}{c|}{} & \multicolumn{1}{c|}{ Purchase } & Inventory & Waste & Transportation & \multicolumn{1}{c|}{ Chain } \\
\hline Agile & $16.8 \%$ & $24.4 \%$ & $24.3 \%$ & $210.8 \%$ & $24.3 \%$ \\
\hline Responsive & $-22.0 \%$ & $-30.7 \%$ & $-30.5 \%$ & $400.0 \%$ & $-30.5 \%$ \\
\hline Lean & $\mathbf{- 2 0 . 9 \%}$ & $\mathbf{- 3 2 . 7 \%}$ & $\mathbf{- 3 2 . 8 \%}$ & $\mathbf{- 5 0 . 0 \%}$ & $\mathbf{- 3 2 . 8 \%}$ \\
\hline Flexible & $21.5 \%$ & $31.0 \%$ & $30.9 \%$ & $0.0 \%$ & $30.9 \%$ \\
\hline
\end{tabular}

Table 9a. Percentage Change cost for Mango

\begin{tabular}{|l|r|r|r|r|r|}
\cline { 2 - 6 } \multicolumn{1}{c|}{} & \multicolumn{5}{c}{ Percentage improvement of cost over current, Orange } \\
\cline { 2 - 6 } \multicolumn{1}{c|}{} & \multicolumn{1}{c|}{ Purchase } & Inventory & Waste & \multicolumn{1}{c|}{ Transportation } & \multicolumn{1}{c|}{ Chain } \\
\hline Agile & $18.8 \%$ & $19.0 \%$ & $19.5 \%$ & $210.8 \%$ & $19.5 \%$ \\
\hline Responsive & $\mathbf{- 2 3 . 6 \%}$ & $\mathbf{- 2 3 . 9 \%}$ & $\mathbf{- 2 4 . 3 \%}$ & $400.0 \%$ & $\mathbf{- 2 4 . 3 \%}$ \\
\hline Lean & $\mathbf{- 2 3 . 6 \%}$ & $-23.6 \%$ & $-24.1 \%$ & $\mathbf{- 5 0 . 0} \%$ & $-24.1 \%$ \\
\hline Flexible & $23.6 \%$ & $23.9 \%$ & $24.3 \%$ & $0.0 \%$ & $24.3 \%$ \\
\hline
\end{tabular}

Table 9b. Pe.rcentage Change cost for Orange

\begin{tabular}{|l|r|r|r|r|r|}
\cline { 2 - 6 } \multicolumn{1}{c|}{} & \multicolumn{5}{c}{ Percentage improvement of cost over current, Tangerine } \\
\cline { 2 - 6 } \multicolumn{1}{c|}{} & \multicolumn{1}{c|}{ Purchase } & Inventory & Waste & Transportation & \multicolumn{1}{c|}{ Chain } \\
\hline Agile & $34.5 \%$ & $36.7 \%$ & $36.7 \%$ & $210.8 \%$ & $36.7 \%$ \\
\hline Responsive & $\mathbf{- 4 3 . 1 \%}$ & $-45.8 \%$ & $-45.8 \%$ & $400.0 \%$ & $\mathbf{- 4 5 . 8 \%}$ \\
\hline Lean & $\mathbf{- 4 3 . 1 \%}$ & $\mathbf{- 4 5 . 9 \%}$ & $\mathbf{- 4 5 . 9 \%}$ & $\mathbf{- 5 0 . 0} \%$ & $\mathbf{- 4 5 . 8 \%}$ \\
\hline Flexible & $43.1 \%$ & $45.7 \%$ & $45.8 \%$ & $0.0 \%$ & $45.8 \%$ \\
\hline
\end{tabular}

Table 9c. Percentage Change cost for Tangerine.

The results are not conclusive, each agent has different interests depending on the chain and the performance measures, there is a trade-off.

\subsection{Dynamic Analysis}

In order to show the dynamic behavior of the variables for the supply chain perishable fruit, the five structures were simulated for a time period of 10 years. This allowed an evaluation of the measures over time for each chain and its agents. All chains are illustrated below in Annex A. 


\section{Conclusions}

Using a model under the system dynamics paradigm the impact of lean, agile, flexible and responsive structures on logistic performance in perishable food supply chains and food security was evaluated. The model was applied to the SC of mango, orange and tangerine and included characteristics of PFSC such as perishability.

The results show that the strategies improve the logistics behavior of the whole chain. However each strategy improves only some measures of logistic performance, not all. While some agents benefit others can be harmed which means that each agent of the chain would apply the best structure according to their own interests, to the detriment of the consumer. The lower levels of inventories and the greatest efficiency are achieved with the responsive and lean structures while the greater food in flow is achieved with the flexible structure. With regards to food security, the lean and responsive structure contributes with access as they are cost efficient, while the agile and flexible provide availability as they improve delivery speed and reduces losses. However, for the three SCs evaluated the responsive structure has the lowest losses in the whole SC and the flexible has the lowest transport losses.

The results derive from the need to carry out studies with mixtures of structures, complemented with trade-off analysis and with multiobjective models.

\section{Acknowledgement}

We thank Fredy, S., Morales, A., Laura, F. and Mejía, F. as well as all the students of the GICALyT group for their tenacity, integrity and dedication, the rigor with which they developed their work has become a great input to carry out this work.

\section{Reference}

Agarwal, A., Shankar, R., \& Tiwari, M.K. (2006). Modeling the metrics of lean, agile and leagile supply chain: An ANP-based approach. European Journal of Operational Research, 211-225. https://doi.org/10.1016/j.ejor.2004.12.005

Agronet. http://www.agronet.gov.co/estadistica/Paginas/default.aspx

Aragón-Correa, J.A., Senise-Barrio, M.E., \& Matías-Reche, F. (1998). Estrategia, Estructura organizativa y desempeño medioambiental: repercusiones del ajuste. Investigaciones Europeas de Dirección y Economía de la Empresa, 41-56. 
Aramyan, L., Ondersteijn, C., Van Kooten, O., \& Lansink, A. (2006). Performance indicators in agri-food production chains. Quantifying the Agri-food Supply Chain, 47-64. https://doi.org/10.1007/1-4020-4693-6_5

Asohofrucol (2014). http://www.asohofrucol.com.co/fruta detalle.php?id=64

Bourlakis, M., Maglaras, G., \& Fotopoulos, C. (2012). Creating a "best value supply chain"? Empirical evidence from the Greek food chain. The International Journal of Logistics Management, 23(3), 360382. https://doi.org/10.1108/09574091211289228

Bourlakis, M., Maglaras, G., Aktas, E., Gallear, D., \& Fotopoulos, C. (2014). Firm size and sustainable performance in food supply chains: Insights from Greek SMEs. International Journal of Production Economics, 152, 112-130. https://doi.org/10.1016/j.ijpe.2013.12.029

Christopher, M., \& Peck, H. (2004). Building the resilient supply chain. International Journla of Logistics Management, 1-13. https://doi.org/10.1108/09574090410700275

Cozzolino, A., Rossi, S., \& Conforti, A. (2012). Agile and lean principles in the humanitarian supply chain: The case of the United Nations World Food Programme. Journal of Humanitarian Logistics and Supply Chain Management, 2(1), 16-33. https://doi.org/10.1108/20426741211225984

Cook, R.L. (2002). The U.S. fresh produce industry: an industry in transition. Postharvest Technology of Horticultural Crops, (third ed.). Vol. 3311. Oakland, CA, USA: University of California Agriculture \& Natural Resources,.

Dabbene, F., Gay, P., \& Sacco, N. (2008a). Optimisation of fresh-food supply chains in uncertain environments. Part II: A case study. Biosystems Engineering, 99(3), 360-371. https://doi.org/10.1016/j.biosystemseng.2007.11.012

Dabbene, F., Gay, P., \& Sacco, N. (2008b). Optimisation of fresh-food supply chains in uncertain environments. Part I: Background and methodology. Biosystems Engineering, 99(3), 348-350. https://doi.org/10.1016/j.biosystemseng.2007.11.012

DANE. (2014). Encuesta Nacional Agropecuaria.

www.dane.gov.co, https://www.dane.gov.co/index.php/agropecuario-alias/estadisticas-agricolas-y-pecuarias-ena

DANE. (s.f.). Estimación y proyección de población nacional, departamental y municipal total por área 1985-2020. http://www.dane.gov.co/files/investigaciones/poblacion/proyepobla06 20/Municipal area 1985-2020.xls

Faostat. http://statistics.amis-outlook.org/data/index.html

Fisher, M. (1997). What is the Right Supply Chain for Your Product? Harvard Business Review, 105-116.

Forrester, J.W. (1958). Industrial Dynamics: A Major Break through for Decision Makers. Harvard Business Review, 36(4), 37-66. 
Gattorna, J. (2015). Dynamic Supply Chain (Vol. 3). Edingurgh, UK: Pearson Education Limited.

Giachetti, R., Martinez, L., Sáenz, O., \& Chin-Seng, C. (2003). Analysis of the structural measures of flexibility and agility using a measurement theoretical framework. International Journal of Production Economics, 47-62. https://doi.org/10.1016/S0925-5273(03)00004-5

Gunasekaran, A., Lai, K.H., \& Cheng, E. (2008). Responsive supply chain: A competitive strategy in a networked economy. Omega The International Journal of Management Science, 549-564. https://doi.org/10.1016/j.omega.2006.12.002

Gustavsson, J., Cederberg, C., Sonesson, U., Van Otterdijk, R., \& Meybeck, A. (2011). Global food losses and food waste. Food and Agriculture Organization of the United Nations, Rome.

Harrison, A., \& Van Hoek, R. (2008). Logistics Management and Strategy (3 ed.). Harlow: Pearson.

Lee, H. (2002). Aligning Supply Chain Strategies with Product Uncertainties. California Management Review Reprint Series. https://doi.org/10.2307/41166135

Lyons, A.C., \& Ma'aram, A. (2014). An examination of multi-tier supply chain strategy alignment in the food industry. International Journal of Production Research, 527, 911-1925. https://doi.org/10.1080/00207543.2013.787172

Lowe, T.J., \& Preckel, P.V. (2004). Decision technologies for agribusiness problems: a brief review of selected literature and a call for research. Manufacturing \& Service Operations Management, 6(3), 201-208. https://doi.org/10.1287/msom.1040.0051

Malorgio, G., \& Felice, A. (2014). Trade and logistics: The fruit and vegetables industry. Mediterra 2014, 149-171.

Manjavacas, M. \& FAO (2012). La producción mundial de fruta tropical. http://www.fao.org/agronoticias/agronoticias/detalle/es/c/159358/ (Accessed: February 2017).

Manson-Jones, R., \& Towill, D.R. (1999). Total cycle time compression and the agile supply chain. International journal of production economics, 61-73. https://doi.org/10.1016/S0925-5273(98)00221-7

Miranda, D. (2011). Estado actual de fruticultura colombiana y perspectivas para su desarrollo. Revista Brasileira de Fruticultura, 199-205.

Myerson, P. (2012). Lean Supply Chain and Logistics Management. New York, EEUU: McGraw Hill.

Naim, M.M., \& Gosling, J. (2011). On leanness, agility and leagile supply chains. International Journal Production Economics, 342-354. https://doi.org/10.1016/j.ijpe.2010.04.045 
Naylor, J.B., Naim, M.M., \& Berry, D. (1999). Leagility: Integrating the lean and agile manufacturing paradigms in the total supply chain. International Journal of Production Economics, 107-118. https://doi.org/10.1016/S0925-5273(98)00223-0

Orjuela-Castro, J.A., Casilimas, W, \& Herrera R.M. (2015). Impact analysis of transport capacity and food safety in Bogota. In Engineering Applications-International Congress on Engineering (WEA), 2015 Workshop on (1-7). Bogotá: IEEE-Xplore. https://doi.org/10.1109/WEA.2015.7370138

Orjuela-Castro, J.A., \& Adarme-Jaimes, W. (2014). Identificación de asimetrías en los medios de almacenamiento and transporte en la cadena de frutas colombiana. Primer Congreso Internacional Industria y Organizaciones, Logística para la Competitividad (1-7). Bogotá: Universidad Nacional.

Orjuela-Castro, J.A., Castañeda-Moreno, I., Canal-Roa, J.L., \& River-Velasco, J. (2015). La Logística en la Cadena de Frutas. Frutas y Hortalizas, 39, 10-15.

Orjuela-Castro, J.A., Caicedo-Otavo, A.L., Ruiz-Moreno, A.F., \& Adarme-Jaimes, W. (2016). Efecto de los mecanismos de integración externa en el desempeño logístico de cadenas Frutícolas. Un enfoque bajo dinámica de sistemas. Revista Colombiana de Ciencias Hortículas, 10(2), 311-322.

Orjuela-Castro, J.A., Calderón, C., \& Calderón, M.E. (2007). Análisis de la Cadena de Valor en las Estructuras Productivas de Uchuva y Tomate de Árbol en la Provincia de Sumapaz y el Distrito Capital. Ingeniería, 13(2), 4-12.

Orjuela-Castro, J.A., Herrera-Ramírez, M.M., \& Adarme-Jaimes, W. (2017). Warehousing and transportation logistics of mango in Colombia: A system dynamics model. Revista Facultad de Ingeniería, 26(44), 71-84. https://doi.org/10.19053/01211129.v26.n44.2017.5773

Orjuela-Castro, J.A., Sepulveda-Garcia, D.A., \& Ospina-Contreras, I.D. (2016). Effects of Using Multimodal Transport over the Logistics Performance of the Food Chain of Uchuva. Applied Computer Sciences in Engineering. Third Workshop on Engineering Applications, WEA. 165-177. https://doi.org/10.1007/978-3-319-50880-1_15

Palacio-Pelaéz, Á.E. (2014). Modelos productivos para la sostenibilidad y el desarrollo. Frutas \& Hortalizas, Revista de La Asociación Hortifurticola de Colombia, 33, 5.

Perez, F., Caplice, C., Singh, M., \& Sheffi, Y. (2014). Expresing a Supply Chain Strategy as a conceptual System. https://dspace.mit.edu/, http://hdl.handle.net/1721.1/103008 (Accessed: January 2017)

Qin, Y. (2011). On Flexible Strategy for Operation Risk in Supply Chain. Fourth International Joint Conference on Computational Sciences and Optimization. 566-569. https://doi.org/10.1109/CSO.2011.184 
Rong, A., Akkerman, R., \& Grunow, M. (2011). An optimization approach for managing fresh food quality throughout the supply chain. International Journal of Production Economics, 131(1), 421-429. https://doi.org/10.1016/j.ijpe.2009.11.026

Ruiz-Moreno, A.F., Caicedo-Otavo, A.L., \& Orjuela-Castro, J.A. (2015). Integración Externa en las Cadenas de Suministro Agroindustriales: Una Revisión al Estado del Arte. Ingeniería, 20(2), 9-30.

Simchi-Levi, D. (2010). Operations Rules: delivering customer, value through, flexible operations. Cambridge: The Mit Press.

Simchi-Levi, D., Schmidt, W., \& Wei, Y. (2014). From superstorms to factory fires: managing unpredictable supplychain dismptions. Harvard Bursiness Review.

Srinivasan, M.M. (2012). Building Lean Supply Chain with the Theory of Constraints. New York, EEUU: McGraw Hill.

Sterman, J. (2000). Bussiness Dynamics: Systems Thinking. United States: McGraw Hill.

Stevenson, M., \& Spring, M. (2007). Flexibility from a supply chain perspective: definition and review. International Journal of Operations \& Production Management, 27(7), 685-713. https://doi.org/10.1108/0144357071075+6956

Van der Vorst, J.G., Van Dijk, S.J., \& Beulens, A.J. (2001). Supply chain design in the food industry. The International Journal of Logistics Management, 12(2), 73-85. https://doi.org/10.1108/09574090110806307

Van der Vorst, J. (2005). Performance measurement in agri-food supply chain networks. An overview. In Quantifying the Agri-food Supply Chain. Springer. 15-26.

Widodo, K.H., Nagasawa, H., Morizawa, K., \& Ota, M. (2006). A periodical flowering- harvesting model for delivering agricultural fresh products. European Journal of Operational Research, 170(1), 24-43. https://doi.org/10.1016/j.ejor.2004.05.024

Yu, M., \& Nagurney, A. (2013). Competitive food supply chain networks with application to fresh produce. European Journal of Operational Research, 224(2), 273-282. https://doi.org/10.1016/j.ejor.2012.07.033

Zanoni, S., \& Zavanella, L. (2012). Chilled or frozen? Decision strategies for sustainable food supply chains. International Journal of Production Economics, 140(2), 731-736. https://doi.org/10.1016/j.ijpe.2011.04.028

Zhang, G., Habenicht, W., \& Spieß, W. (2003). Improving the structure of deep frozen and chilled food chain with tabu search procedure. Journal of Food Engineering, 60(1), 67-79. https://doi.org/10.1016/S02608774(03)00019-0 


\section{Annex A}

\section{Dynamic Behaviour of the Performance Measures for the All Chains}

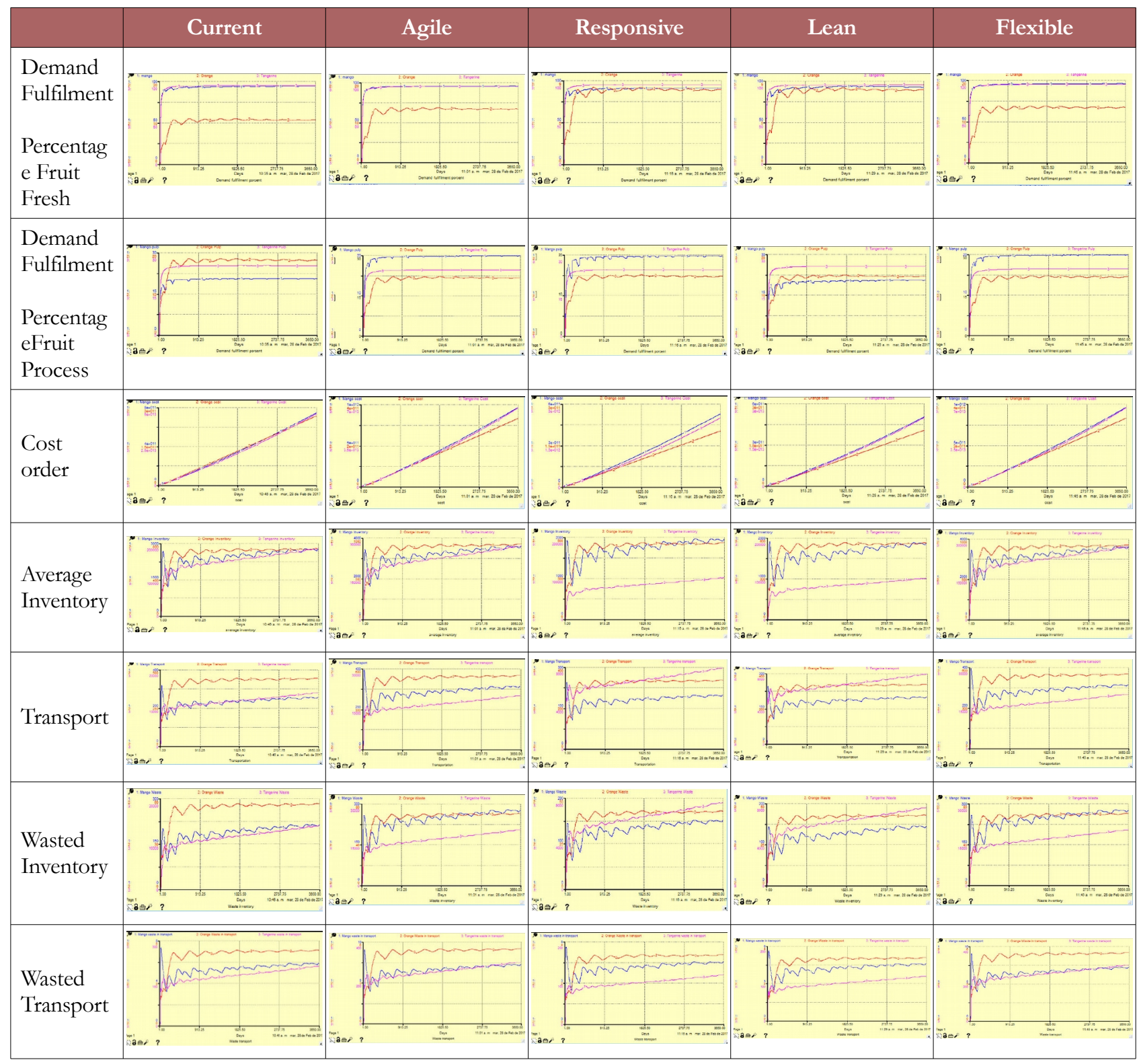

Journal of Industrial Engineering and Management, 2017 (www.jiem.org)

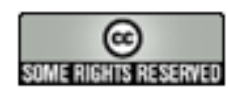

Article's contents are provided on an Attribution-Non Commercial 3.0 Creative commons license. Readers are allowed to copy, distribute and communicate article's contents, provided the author's and Journal of Industrial Engineering and Management's names are included. It must not be used for commercial purposes. To see the complete license contents, please visit http://creativecommons.org/licenses/by-nc/3.0/. 